\title{
INTERNALIZATION MANAGEMENT OF RELIGION VALUES THROUGH ISLAMIC EXTRACURRICULAR ACTIVITIES FOR THE ESTABLISHMENT OF CHARACTERS OF STUDENTS OF SMAN 1 MALANG
}

\author{
I'anatut Thoifah, M.Pd.I \\ Universitas Muhammadiyah Malang, Indonesia \\ Email: thoifah@umm.ac.id
}

\begin{abstract}
Abstrak: This study aims to investigate the planning, implementation, and evaluation of religious value internalization through an Extracurricular program of Islamic religious division and its relevance to a character building at SMAN 1 Malang. The data collections of this study were observation, interview, and documentation. In analyzing the data, the researcher used qualitative descriptive analysis which mean s that she described and interpreted the data to figure out the phenomenon in a real condition. The result of this study showed that the member of students in Islamic religious division planned and implemented the programs and activities based on the religious value through materials, methods, and times they arranged. Besides, the internalization management of religious value through this extracurricular program has relevance to a character building. This extracurricular program also facilitates the students to implement their knowledge into a good character based on religious value. In other words, the students can apply their experience they have got in the classroom into the activities in the extracurricular program, to have a good character, in which it also becomes the purpose and the relevance of internalization management of religious value through an extracurricular program and character building.
\end{abstract}

Keywords: Management of Internalization of Religious Values; Extracurricular Section of Islamic Spirituality; Character Education

\section{PREFACE}

In accordance with the objectives of education in the National Education System Act (Sisdiknas) Chapter II that national education aims to develop the potential of students to become human beings who are faithful, pious, noble, healthy, knowledgeable, capable, creative, independent and citizens of the country democratic and responsibility (Republic of Indonesia Law 2003, 2006: 76). Then in carrying out education, it is not motivated by intra education, but also through extras which can achieve national education goals.

Frankl (1985) said, "People have to live, but nothing to live for; "They have the means, but no meaning." Now that humans or corporations today need 'meaning and value' in every step of their lives. However, many people are blind to their eyes so they cannot know who they are as in the word of God.

"So have they not traveled through the earth and have hearts by which to reason and ears by which to hear? For indeed, it is not eyes that are blinded but blinded are the hearts which are within the breasts" (Al-Hajj 22:46).

Based on a survey in the United States in 1918 about IQ, it was found "paradox" to endanger: "while children's IQ scores were higher, their emotional intelligence dropped. More worryingly, data from a massive survey of 1970 and 1980 on parents and teachers showed, "Children of the current generation are more often experiencing emotional problems than their previous generation. On an average basis, children are now growing lonely and depressed, irritable and unruly, more nervous and tend to be anxious, impulsive and aggressive. " (Ginanjar, 2009: 6)

In such conditions, perhaps humans will experience massive inner conflicts. The conflict is an impact of the imbalance between the ability of science and technology to produce a material culture 
with a spiritual vacuum. An internal shock that is expected to hit humanity perhaps will affect the psychological life of humans. In this condition, humans will seek inner tranquility, including religion. This is also probably due to the emergence of futurology predictions that in the era of religious globalization will affect the human psyche (Jalaluddin, 2003: 195).

"A religious attitude is a condition that exists in someone who encourages him to behave by the level of his obedience to religion. The religious attitude is the consistency between belief in religion as a cognitive element, feeling towards religion as an effective element and behavior towards religion as a psychomotor element. So the religious attitude is a complex integration between religious knowledge, religious feelings and religious acts in a person. This shows that religious attitudes are related or closely related to psychiatric symptoms "(Jalaluddin, 2003: 199).

Whereas the Religious Extracurricular in schools, especially middle school age (SMA/ SMK), is sufficient to represent the presentness of this comprehensive tarbiyah Islamic process. This phase is a phase that is very useful for the growth of one's spiritual quotient, namely the period of the initiation of physical, intellectual, and psychological maturity, to be able to capture lessons and teaching well for his benefit "(Hasanah, 2010: 26).

This study focused on how planning, implementation, evaluation of internalization of religious values through extra-curricular activities of Islamic Spirituality in students of SMAN 1 Malang and its relevance to character education.

\section{RESULTS AND DISCUSSION}

1. Definition of Internalization, values, and religion

Etymologically, internalization shows a process. In the Indonesian language rules, the suffix has a process definition. So that internalization can be defined as a process of instilling something.

In the large dictionary, Indonesian language internalization is interpreted as appreciation, the profound mastery that takes place through coaching, guidance, counseling, upgrading, etc. (Department of Education and Culture, 1989: 336).

The term value is an abstract that cannot be seen, touched, or felt and is not limited in scope. Values are very close to complex notions and human activities, so the boundaries are difficult to determine, because the extractives of the various kinds of understanding arise, including as follows:

a. Value is a set of beliefs or feelings that are believed to be an identity that gives an unusual pattern to patterns of thought, feeling, connection and behavior (Drajat, 1992: 260).

b. Values are references and beliefs in making choices (Mulyani, 2004: 11).

c. Value is a normative pattern, which determines desired behavior for a system that has to do with the surrounding environment without distinguishing the functions of its parts (Arifin, 1987: 141).

Some understanding of the above values can be understood that the value is something abstract, ideal, and involves the issue of belief in the desired, and gives a pattern on patterns of thoughts, feelings, and behavior. Thus to track, a value must be through the meaning of another reality in the form of actions, behavior, mindset, and attitude of a person or group of people.

According to WJS. Poerwadarminta:

Syafaat $(2008,152)$ argues, religion comes from the word religion which means all trust in God. So religion is a trait that exists in religion, while religious values indicate religious values.

Various types of religious values according to Madjid (2000, 98-100), namely a) faith, b) Islam, c) Ihsan, d) taqwa, e) sincerity, f) resignation, g) thanksgiving, h), Patience, These values are fundamental values that must be instilled in children, this activity of instilling educational values is actually the core of religious education.

Internalization of religious values is a process of instilling religious values. Internalization can be through institutional doors or institutional doors such as Islamic institutions and others, personnel doors, namely through individual doors, especially teachers, and material doors through the door of lecture material, or curriculum through a substantial approach, not only limited to Islamic religious education subjects but also through religious activities found in schools.

In the psychological framework, internalization is defined as the incorporation or unification 
of attitudes, behavioral standards, opinions in personality. Freud (in Chaplin, 1993: 256) believes that superego or moral aspects of personality derive from the internalization of parental attitudes (parents). In this case, three stages represent the process/stage of internalization, namely: a) Stage of value transformation, b) Stage of value transactions, c) Transinternalization stage (Muhaimin, 1996: 153).

a. The value transformation phase is a process carried out by educators in informing excellent and bad values. At this stage, there is only verbal communication between the teacher and students.

b. The value transaction stage is a stage of value education by carrying out two-way communication, the interaction between teacher and student in the form of mutual interaction.

c. The trans-internalization stage, this stage is far more profound than the transaction stage, at this stage not only is done with verbal communication but also mental and personality attitudes, at this stage personality communication plays an active role.

Associated with human development, the internalization process must go according to developmental tasks. Internalization is the central process of personality change which is a critical dimension in the acquisition or change of human self, including the personality of meaning (value) or the implication of the response to the definition.

\section{The Urgency of Internalizing Religious Values in High School Students}

The division of the stages of human development, high school level students occupy the level of adolescence, in line with physical and spiritual growth, then religion in youth also influenced by these developments, with other meanings of adolescents appreciation of religious teachings and religious acts seen in adolescents are much related to that is.

Several spiritual and physical development factors characterize religious development in adolescents, such events according to Starbuck (in Jalaluddin, 2008: 74-77) are the growth of mind and mental, feelings, social, moral, attitudes and interests, and worship.

Not infrequently the teenagers take shortcuts to overcome the inner turmoil they experience. In such conditions, usually, peer groups play a role in making choices. Internal escape sometimes helps trap them in the direction of harmful and destructive actions. Drug cases, brutality, and criminal acts are part of the failure of teenagers to find a way of life that can reassure their inner turmoil (Jalaluddin, 2008: 82)

Therefore, the internalization of religious values is very important for the development of high school level students. Because high school students are teenagers whose atmosphere of the inner life is still vacillating (Strum and Drang). To overcome the emotional turmoil, they should need guidance and direction, both from the family, the community, and the school by instilling religious values in students.

Mazguru (2010) says, there are several attempts to internalize religious values in students, namely: indoctrination approach, moral reasoning approach, forecasting consequence approach, a value classification approach, and ibrah and amtsal approach.

First, the indoctrination approach, which is an approach used by teachers to doctrine or instills subject matter with the element of force to be mastered by students. The things that can be done by the teacher in this approach are.

a. Brainwashing, that is, the teacher starts value education by destroying established values in students to be confused.

b. Planting fanaticism, namely the teacher instilling new ideas or values that are considered right.

c. Planting doctrine, that is, the teacher introduces a truth value that students must accept without having to question the nature of the truth.

Second, the approach to moral reasoning, which is an approach used by teachers to present material related to morals through logical reasons to make the right choice. The things that can be done by the teacher in this approach are.

a. The presentation of a moral dilemma is that students are confronted with ethical issues that are contradictory

b. Division of discussion groups, students are divided into several small groups to discuss

c. Class discussions, the results of small group discussions are brought into class discussions to 
obtain students' rationale for taking moral judgment and decisions.

d. Selected value selection, each student can make a selection according to the level of moral development which is used as the basis for ethical decision making and can choose the selected value according to the proposed alternative.

Third, forecasting consequence approach, namely the method used by the teacher with the intention of inviting students to discover the possible consequences of an action. The things that teachers can do in this approach are.

a. Presentation of moral-value cases, students are given an example of moral values that occur in society.

b. Submitting questions, students are led to find values with guiding questions ranging from simple level questions to high-level questions.

c. Comparison of values that occur with what should be.

d. Predicting consequences, students are told to predict the implications of the selection and application of value.

Fourth, the value classification approach, which is an approach used by the teacher to invite students to find an action that contains elements of value (both positive and negative) and then the values that should be found will be found. The things that teachers can do in this approach are.

a. Helps students to find and categorize different types of values

b. The process of setting goals, expressing feelings, exploring and clarifying values.

c. Planning actions.

d. Carry out actions according to the value decisions taken with models that can be developed through moralizing, direct moral cultivation with close supervision, laisez faire; children are given the freedom to practice their choice without supervision, modeling planting values by providing examples to emulate.

Fifth, ibrah and amtsal approach, namely an approach used by the teacher in presenting material with the intention that students can find stories and parables in an event, both those that have occurred and those that have not happened. Things that teachers can do include:

a. Invite students to discover through reading texts or seeing media shows about stories and parables.

b. Ask students to tell it from the story of an event, and find the parables of the people in the story of the fact.

c. Present several stories of an event to be discussed and finding the parable as a result of the story.

In this context, it seems that Sie Islamic spirituality in schools is very much needed because Sie Islamic spirituality is one of the most effective means for schools to internalize religious values in students.

\section{Extra-curricular, Islamic spirituality section}

\section{Understanding Extra Curricular}

In the Indonesian dictionary (1989: 336) Extras are extras outside the official ones, while Curricular is related to the curriculum. So the definition of Extra-Curricular is an activity outside the separating school, or part of the scope of the lessons given in college or secondary education is not an integral part of the subjects that have been defined in the curriculum (KBBI, 1989: 479).

Extra-curricular activities can be categorized as general activities and religious activities (Islamic spirituality) with the aim of forming spiritual souls in students that are following Islamic religious values, the primary goal is to shape educated and fearful people to Allah.

\section{Definition of Sie Islamic Spirituality (SKI)}

According to the 2010-1011 Islamic Spiritual Education Decree, this organization is a nuanced Islamic organization under the auspices of the intra-school student organization (OSIS) 
Malang 1 Public High School. Sie Islamic Spirituality (SKI) is not a community organization, but an organization based on training and education which consists of all Malang State High School 1 student who is Muslim as well as those who hold the Islamic Spirituality Management in SMA Negeri 1 Malang, which has several objectives, including.

a. Gathering and fostering members who are Muslim to become Indonesian citizens who have faith and devotion to the Almighty God.

b. Practice and broadcast Islam.

c. Build character and independence, nurturing and enhancing brotherhood, kinship, unity, and unity, realizing intact cooperation and promoting a sense of dynamic responsibility and creativity as well as awareness among members.

d. Form a complete Indonesian human who has mental resilience, extensive knowledge, and technical skills to be able to carry out activities for his future.

Among the functions of the Islamic Spirituality section organization are :

a. Drivers and initiators of reform by organizing constructive and nuanced Islamic activities,

b. A place for fostering and developing potential members in improving the quality of faith and loyalty to God Almighty in everyday life,

c. Strengthen collaboration among members in each activity for the integrity and success of activities.

\section{Character building}

\section{Definition of Character Education}

The term character comes from the Latin character, which means character, character, psychological traits, character, personality or morals (Oxford). Whereas in terms of terms, the character is defined as human nature, which in general humans have many traits and depend on their factors of life. Character is a mental, moral or character that are characteristic of a person or group of people, in the term mentioned that the stamp of individually or group is impressed by nature, education or habit which means character is the values of human behavior that is related to God Almighty, himself, fellow human beings, environment, and nationality are manifested in thoughts, attitudes, feelings, words, and actions based on religious norms, law, manners, culture, and customs.

According to (Thobroni, 2011) interpreting character as morality and character, so that the nation's character is identical with the nation's morals or the nation's character. A government with character is a nation that has character and virtue, whereas a government that is not characterized is a nation that is not or lacks character or does not have proper norms and behavior standards.

\section{Basic Character Formation}

The value of good or bad is the primary basis in the formation of one's character. Good value is symbolized by spiritual value, and bad value is expressed by Satanic value, human character is the result of attraction between values in the form of positive energy and bad values in the way of negative energy. Positive energy in the form of religious, ethical values derived from belief in God, while negative energy in the form of moral values derived from taghout (demon).

Moral-ethical values function as a means of purification, purification, and generation of genuine human values (conscience); in this case, there is some positive energy. First, spiritual power, spiritual power in the form of îmân, Islam, ihsân and taqwa, which function to guide and give strength to humans in reaching glory and glory (ahsani taqwîm). Second, the power of positive human potential, in the form of al-âql al-salîm (healthy mind), al-qalb al-salîm (healthy heart), al-qalb almunîb (heart that returns, clean, holy from sin) and al-nafs al-mutmainnah (calm soul), all of which are human capital or human resources that have extraordinary powers. Third, ethical attitude and behavior is the implementation of spiritual power and the strength of human personality which then gives birth to normative concepts of ethical, cultural values which include: istiqâmah (integrity), ihlâs, jihād, and religious charity.

According to Thobroni (2011), positive energy in the perspective of individuals will give birth to people of character, namely people who are devoted, have integrity (al-nafs al-muthmainnah) and do good deeds. The actualization of qualified people, in life and work, will give birth to noble character, because they have the personality (integrity, commitment, and dedication), capacity (skills), and good competency (professional). 


\section{CONCLUSION}

1. To internalize religious values in Malang State High School I, there are several planning and standardization to be achieved, namely: faith, piety, morality, and discipline, from which standards are formed several planning activities such as PHBI (commemoration of Islamic holidays), Diklat Sie members of Islamic Spirituality, publishing Islamic books, making da'wah bulletins, religious lectures and other matters related to religion.

2. Implementation of Islamic Spirituality in internalizing religious values in Malang State High School in the form of activities implemented through material that discusses religion, including faith, piety, and morality. Besides religion, there is also what is called keputrian and material about social. The method used in implementing religious values in SMA 1 Malang is through the lecture method (the teacher explains the material), the demonstration method (students apply everything they get from previous material). The time used is on Friday for routine, Wednesday, Sunday for motivational training, national day, and also the anniversary of Islam (PHBI). Timing is one way to succeed in an activity.

3. Results of the analysis Evaluation of the planning and implementation of extra-curricular activities in Islamic Spirituality in Malang State High School 1 found supporting factors such as teacher cooperation, student activity, parent and community collaboration and facilities, and infrastructure. While the inhibiting factor is the clash of Islamic Spirituality activities with other events, inadequate facilities and infrastructure, and monotonous activities. From the supporting and inhibiting factors, the solutions offered are an improvement of work programs, selection of responsible cadres, method development and progression of facilities and infrastructure.

4. Management of internalization of religious values through extra-curricular activities in Islamic Spirituality in Malang State High School 1 students has relevance to character education which also teaches about religious values in the form of faith, Islam, Ihsan, loyalty, sincerity, resignation, and gratitude. Also, the extra-curricular activities of Islamic Spirituality in SMA Negeri 1 Malang students are facilities for students to apply their knowledge into a character that reflects religious values. Students can apply the knowledge they obtain from the class in activities that have been programmed by Sie Islamic Spirituality so that students can reflect religious values into their character. This is the purpose and relevance of management internalization of religious values through extra-curricular activities of Islamic Spirituality and character education.

\section{Bibliography}

Aat Syafaat, TB. et al., 2008. Peranan Pendidikan Islam. Jakarta: Rajawali Pers.

Arifin, M. 1987. Filsafat Pendidikan Islam. Jakarta: Bina Aksara.

Chaplin, James. 1993. Kamus Lengkap Psikologi. Jakarta: PT Raja Grafindo Persada.

Departemen Agama RI. 1995. Al-Qur'an dan Terjemahnya. Semarang: PT Toha Putra.

Frankl, Viktor E. 1985. Man's Search For Meaning. Washington: First Washington Square Press.

Ginanjar, Ary 2009. ESQ. jakarta: ARGA Publishing.

Hasanah, Kholifatu. 2010. Skripsi "Internalisasi Nilai-nilai Agama Melalui Kegiatan Ekstrakurikuler Badan Dakwah Islam (BDI) dalam Peningkatan Kepribadian Muslim Pada Siswa SMA Negeri 8 Malang".

Jalaluddin. 2003. Psikologi Agama. Jakarta: PT Raja Grafindo.

2008. Psikologi Agama. Jakarta: PT Raja Grafindo Persada.

Majdjid, Nurcholish. 2000. Masyarakat Religius Membumikan Nilai-Nilai Islam Dalam Kehidupan Masyarakat. Jakarta. 
Mazguru, Internalisasi Nilai-nilai Agama untuk Membentuk Kepribadian Muslim, (http://mazguru.wordpress.com/category/tasawuf/. diakses 24 Desember 2010).

Muhaimin. 1996. Strategi Belajar Mengajar. Surabaya: Citra Media.

Mulyani, Rohmat. 2004. Mengartikulasikan Pendidikan Nilai. Bandung: Alfabeta

Pusat Pembinaan dan Pengembangan Bahasa Departement Pendidikan dan Kebudayaan, 1989. Kamus Besar Bahasa Indonesia. Jakarta: Balai Pustaka.

SK Studi Kerohanian Islam SMA Negeri 1 Malang. 2010-2011.

Tobroni, Pendidikan Karakter Dalam Perspektif Islam (http://tobroni.staff.umm.ac.id. diakses 09 April 2011).

Undang-Undang Republik Indonesia Nomor 20 Tahun 2003 tentang Sistem Pendidikan Nasional. 2006 Bandung: Citra Umbara.

Zakiyah Drajat. 1992. Dasar-dasar Agama Islam. Jakarta: Bulan Bintang. 